\begin{tabular}{|c|c|}
\hline & $\begin{array}{l}\text { Jurnal Penelitian dan Evaluasi Pendidikan } \\
\text { Volume 23, No 2, December } 2019 \text { (206-218) }\end{array}$ \\
\hline an dan Evaluasi I & Online: http://journal.uny.ac.id/index.php/jpep \\
\hline
\end{tabular}

\title{
THE EFFECT OF PARENTING STYLE AND GENETIC PERSONALITY ON CHILDREN CHARACTER DEVELOPMENT
}

\author{
Masduki Asbari \\ Universitas Pelita Harapan \\ Wakbida Nurbayati \\ Aya Sophia Islamic School \\ Agus Purwanto \\ Universitas Pelita Harapan
}

\begin{abstract}
Character building is very important to become a key for educational mainstream in Indonesia, either in a formal, non-formal, and informal setting. Several factors influence character building in children, namely parenting style and genetic personality. The purpose of this research is to identify the influence of parenting style and genetic personality to children's character development. This research is a correlational study using a survey and quantitative method. The population in this study were parents of students in Aya Sophia Foundation Islamic School. Data collection was carried out by simple random sampling to a population of 1,243 students' parents using an electronic questionnaire. The returned and valid questionnaire results were 398 samples. The data collection technique used was a questionnaire with a Likert scale. The instrument of this study is a modification from the Parenting Style Questionnaire (PSQ) of Robinson et al. and Roman et al. To measure the genetic personality, the instrument was adapted from STIFIn Personality Concept. Another instrument used to measure children's character development is an adaptation from Poniman et. al. The analysis in this study used SEM (Structural Equation Model) with SmartPLS version 3.0 as a statistic tool. The result of this study shows that parenting style and genetic personality have a positive influence and significantly contribute to children's character building.
\end{abstract}

Keywords: children character building, parenting style, personality genetic, STIFIn personality

Permalink/DOI: http://dx.doi.org/10.21831/pep.v23i2.28151

\author{
Contact: Agus Purwanto \\ agozpor@gmail.com \\ Department of Management, Universitas Pelita Harapan \\ Jl. M. H. Thamrin Boulevard 1100 Lippo Village, Tangerang 15811, Indonesia
}




\section{Introduction}

Indonesia currently faces major challenges, which is decentralization and the era of total globalization. The key to success in facing these challenges is to prepare the quality of human resources that is complete, reliable, and cultured (Puspitawati \& Sarma, 2012), meaning that those who can save the nation's condition are human resources with character. Bung Karno, one of the founding fathers of the nation, stressed: "This nation must be built by prioritizing character building because this character will make Indonesia a great, advanced, and glorious, dignified nation" (Samani \& Hariyanto, 2011).

Character education has been coloring the curriculum in Indonesia since the old order, using the term character education with an emphasis on relationships between people, between students and teachers, between students and parents, and between students. Until now, the implementation of character education is still the main mainstream. At the peak of the National Education Day commemoration on May 2, 2010, Susilo Bambang Yudhoyono, as the President of the Republic of Indonesia, launched the National Movement for Nation Character Building (Samani \& Hariyanto, 2011).

Curriculum Center for the Research and Development Agency of the Ministry of National Education (2011) states that character education aims to form a strong, competitive, noble, moral, tolerant, mutual cooperation, patriotic-spirited, dynamic-developing, science-and-technology oriented human resources, all of which are imbued with faith and piety to God Almighty. This character education must take place both in formal education (in foundations, primary school/Madrasah Ibtidaiyah, junior secondary school/Madrasab Tsanawiyah, senior secondary school/vocational secondary school/ Madrasah Aliyah, and college), non-formal education, and informal education in the family.

Although character education has become a common concern, it turns out that the picture of the community's situation and even the world of education in Indonesia is still concerning. The cases of brawls between students and other forms of juvenile delinquency, bullying, promiscuity, and also drug use are increasing. Corruption cases are even more widespread. In the country, discipline culture, a clean and healthy life, and also respect for the environment are still far below the standard.

Setiawan (2018) reported that the Indonesian Child Protection Commission noted that many Indonesian children were used as drug couriers during 2017. Children became vulnerable because Indonesia was an easy target for drug trafficking. Commissioner of the Center of Indonesian Child Protection Commission (Komisi Perlindungan Anak Indonesia or KPAI), Putu Elvina, said many cases of children dealing with the law include drugs. She mentioned, the number was quite good, namely, during 2017, it is around 22 cases of children who became drug couriers. Then in the same year, there were around 46 children who became vicims of drug abuse. Meanwhile, Afifah (2019) said that KPAI Chair, Susanto, said that in 2018, cases of children dealing with law ranked first, which is 1,434 cases, then followed by cases related to family and childcare as many as 857 cases.

Puspitawati and Sarma (2012) state that to solve the problem of quality human resources in this country, especially related to the quality of children, a holistic approach that combines family and education systems is needed. The condition of the family is very dependent on the surrounding environment, and vice versa, that the family also affects the surrounding environment. Soedarsono in Samani and Hariyanto (2011) explained that the synergy between home (family), school, and community in terms of character education has not been realized properly so that it has not yet had a multidimensional impact. Table 1 illustrates a portrait building character that is still neglected.

Family is the smallest unit in society that is a pillar supporting the existence of a nation. Family institutions become important centers of activity from various aspects of life. In it, there is a family leader who is 
Table 1. Portrait Builds Neglected Characters

\begin{tabular}{|c|c|c|c|}
\hline & Home & School & Society \\
\hline Wisdom old age & Increased spiritual approach & $?$ & Many are apathetic \\
\hline Consolidation of adult age & ? & $!$ & $\begin{array}{l}\text { - Low trust society } \\
\text { - No mutual respect } \\
\text { - No role model }\end{array}$ \\
\hline Development of adolescence & $?$ & $!$ & $\begin{array}{l}\text { - Not conducive } \\
\text { - Orientation on money, } \\
\text { material and worldly }\end{array}$ \\
\hline Early age formation & Many are left to helpers & $!$ & - Not conducive \\
\hline
\end{tabular}

Information: ? = be questioned

Source: (Soedarsono in Samani \& Hariyanto, 2011)

usually attached to a man (head of the family), a household manager who is usually attached to a woman (housewife), and children who have the right to education and teaching of both character, religious, and socio-cultural values. The importance of the role of the family is because the family becomes the first and foremost school for children.

The implementation of family education has a strong legal foundation in Indonesia. In the Law of Republic of Indonesia No. 20 of 2003 concerning the National Education System, it is stated that the education unit is an education service group that organizes education on formal, non-formal, and informal channels at every level and type of education. Informal education is the path of family and environmental education. Government Regulation No. 21 of 1994 states that there are eight functions that must be carried out by the family, including functions to fulfill physical and non-physical needs consisting of religious, social, culture, love, protection, reproduction, socialization and education, economy, and environmental development. The mandate of concerning population and family development aims to improve the quality of the family so that the family members find a sense of safe, peaceful, and hope for a better future in realizing physical welfare and inner happiness. In fact, the Minister of Education and Culture of the Republic of Indonesia formed a new echelon II work unit, namely the Directorate of Family Education Development. The duties of the Directorate are regulated in the Regulation of the Minister of Education and Culture No. 11 of 2015, which is to carry out the preparation of the formulation and implementation policies in the field of fostering family education.

The success of education in the family cannot be separated from the role of parents. Interaction in the early years with parents exerts a persistent and long-term influence on the developmental maturity and success of children's education, especially related to character. Thus, parenting patterns become things that need to be studied and developed continuously. Oktafiany, Solihatin, and Japar (2013) state that there is a correlation between parenting patterns and children's emotional intelligence. Misbach (2010) states that in addition to being influenced by parenting patterns, the characters that appear in children are also influenced by genetic factors. It is reinforced by the opinion of Poniman and Mangussara (2012) that the phenotype is influenced by genetics and the environment (genetic heredity (inheritance) and non-heredity (given)). Genetic personality is a non-heredity nature and genetic structure which is a blueprint of a person's strengths and weaknesses and becomes a "code" of each individual.

The character development of children in Aya Sophia Foundation Islamic School is carried out by considering factors that influence the character of both genetic 
and environmental factors. Children's genetic personality types are identified at the beginning of the school year. The parenting program is carried out in the hope that the parenting applied by parents at home can be in harmony with the conditions of the school environment. However, it is not yet known whether there is a relationship between genetic personality identification and parenting with the character development of children in Aya Sophia Foundation Islamic School.

Based on the aforementioned description, it is important to conduct research in order to examine more deeply the relationship between character development of children with parenting style and genetic personality. The results of the study become an evaluation material for children's character development programs at Aya Sophia Foundation Islamic School. The study of these factors is also expected to provide enrichment regarding character education in the family. In addition, there are still gaps in previous studies that discuss the relationship of parenting (parenting style) and genetic personality as a whole to the child's character development. Several research results related to this study are as follows.

Huver, Otten, de Vries, and Engels (2010) conduct research on the relationship of personality and parenting style in parents of adolescents in the Netherlands, showing that parenting style influences the development of adolescent personality (Huver et al., 2010). In addition, Nyarko (2011) conducts research on the relationship between the authoritative parenting style and adolescents' academic achievement. The components used to measure authoritative parenting style variables include parent's acceptance/support of children, parental supervision/control of children, and parents' psychological aspects. The results show that there is a positive and significant relationship between the authoritative parenting style and children's learning motivation (Nyarko, 2011).

A research by Talib, Mohamad, and Mamat (2011) on the effects of parenting style on children's development shows that the authoritative style has a positive effect on children's attitudes and learning motivation (Talib et al., 2011). Besides, Jonynienè and Kern (2012) studied the psychological lifestyle and parenting in Lithuanian. The research shows that authoritative parenting is carried out by parents who have an optimistic attitude, focus on solutions, have low stress levels, and are responsible and cooperative (Jonyniene \& Kern, 2012). Moreover, Othman and Khairollah (2013) see that there is a positive and significant relationship between the authoritative parenting style and Islamic personality, including worship, trust, and knowledge (Othman \& Khairollah, 2013). Pratiwi and Ekowarni (2015) studied the moral intelligence of Chinese ethnic preschoolers in parenting style. The results show that the moral intelligence of children who receive an authoritative parenting style is higher than the authoritarian parenting style, permissive, and uninvolved (neglectful) (Pratiwi \& Ekowarni, 2015). Hasnain, Faraz, and Adlakha (2013) agree that parenting style influences children's self-esteem and happiness. Through a one-way ANOVA and Turkey Test analysis, it is known that children with authoritative parenting patterns have higher self-esteem and happiness than children with authoritarian and permissive parenting patterns (Hasnain et al., 2013).

On the other hand, Oktafiany et al. (2013) believe that there is a positive correlation between parenting and the emotional intelligence of children, and the best parenting pattern is democratic (Oktafiany et al., 2013). Studying the intention of child prosocial behavior in terms of parenting style, Utomo (2014) reveals that there is a positive correlation between parenting style and children's prosocial behavior (Utomo, 2014).

Most of those previous studies only partially analyze the influence of parenting style and personality on character development. In addition, none of the studies has analyzed genetic personality.

This study consisted of two independent variables, namely parenting style (X1) and genetic personality (X2), and the dependent variable was the development of children's character $(\mathrm{Y})$. Based on the previous 
studies, a research model was developed that illustrates the relationship between variables. The relationship between variables in this research model and the theoretical basis is explained as follows.

The Influence of Parenting Style on the Development of Children's Character

There is an influence between education in the family to the character development of their children. Family is the foundation of the social cooperation unit by involving parents (fathers and mothers) to work together in educating their children (Coleman in Puspitawati \& Sarma, 2012). Huver et al. (2010) state that parenting style influences adolescent personality. In their research, Puspitawati and Sarma (2012) explained that there is a correlation between parenting and the child's self-control abilities. In other words, it is stated that the child's behavior is influenced by the parents' treatment of him. The research results of Abidin (2011) also show that parenting style based on love and high positive acceptance, not ignored, not attacked and not rejected, has a positive effect on children's social behavior. It means that parents who adopt a good parenting style will make the child's social behavior better. It is in line with the research of Oktafiany et al. (2013) that there is a positive correlation between parenting and the emotional intelligence of children. It was further explained that the best parenting is democratic. Based on those explanations, it is suspected that parenting style is related to the character development of children in Aya Sophia Foundation Islamic School.

The Influence of Personality Genetic on Children's Character Development

In the context of nature, a person's character is influenced by a genetic structure which is a blueprint of a person's strengths and weaknesses and becomes a "code" for each individual that is permanent (Misbach, 2010). Genetic personality is an innate character associated with the dominance of the brain's work system. Genetic personality can be determined by the biometry method and the method used in this study is STIFIn fingerprint analysis. In addition, Poniman and Mangussara (2012) state that the phenotype is influenced by genotype and environmental factors. One of the determining genotype factors is genetic personality. Thus, it is suspected that genetic personality influences the character development of children in Aya Sophia Foundation Islamic School.

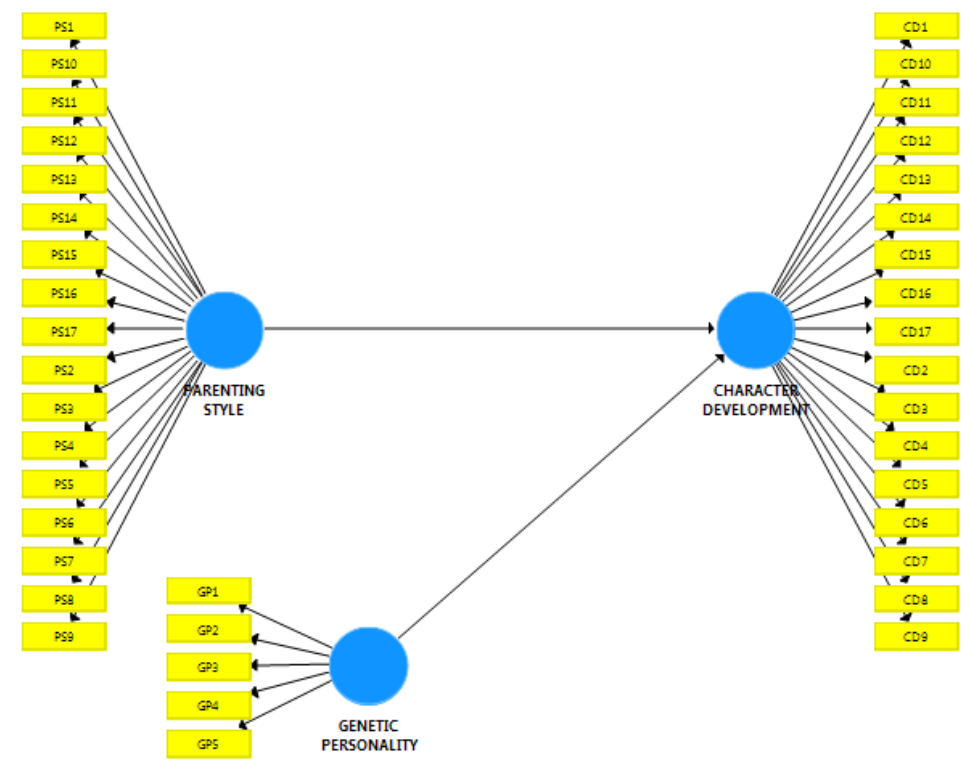

Figure 1. Research Model

Source: Internal data processed by SmartPLS 3.0 
Based on those aforementioned relationships, a research model was designed as illustrated in Figure 1. The research model structures the formulation of the hypothesis proposed in this study, elaborated as follows. H1: Parenting style has a positive and significant effect on the development of children's character in Aya Sophia Foundation Islamic School.

$\mathrm{H} 2$ : Personality genetic has a positive and significant effect on the character development of children in Aya Sophia Foundation Islamic School.

\section{Research Method}

This study aims to determine the effect of parenting style and genetic personality on children's character development at Aya Sophia Foundation Islamic School. Based on the research hypotheses, the research objectives are formulated as follows: (1) knowing the effect of parenting style (X1) on the development of children's character at Aya Sophia Foundation Islamic School $(\mathrm{Y})$, and (2) knowing the influence of personality genetic (X2) on the development of children's character at Aya Sophia Foundation Islamic School (Y).

The research was conducted from September to October 2019 using a survey method with a correlational research approach. Data were collected by distributing questionnaires to students' parents. A modification of the Parenting Style Questionnaire (PSQ) of Robinson, Mandleco, Olsen, and Hart (1995) and Roman et al. (2015) was used to measure the parenting style. The in- strument for measuring genetic personality was adapted from Poniman and Mangussara (2013). Adaptations of Poniman, Nugroho, and Azzaini (2014) were used for measuring children's character development. The questionnaire was designed as closed questions, except for questions/statements about the respondent's identity in the form of a semiopen questionnaire. Each closed question/ statement item gives five options: strongly agree (Sangat Setuju or SS) with score 5, agree (Setuju or S) with score 4, less agree (Kurang Setuju or KS) with score 3, disagree (Tidak Setuju or TS) with score 2, and strongly disagree (Sangat Tidak Setuju or STS) with score 1.

The population in this study was 1,234 parents of students in Aya Sophia Educational Foundation who already know the type of genetic personality of their children through STIFIn fingerprint analysis and are involved in the care of their children. Data were collected by simple random sampling via an electronic questionnaire. The returned and valid questionnaire results were 398 samples. SmartPLS software version 3.0 was used for data analysis since PLS is an analytical method that is soft modeling because it does not assume the data must be of a certain scale measurement (Ghozali, 2014).

\section{Findings and Discussion}

\section{Sample Description}

Several criteria were established in elaborating the characteristics of the sample. Information on the characteristics of the sample is presented in Table 2 .

Table 2. Sample Descriptive Information

\begin{tabular}{lccc}
\hline & Criteria & Amount & Percentage \\
\hline Age of Parent Couple & $<40$ years old & 294 & $73.87 \%$ \\
& $\geq 40$ years old & 104 & $26.13 \%$ \\
\hline Parent Couple Education & Bachelor & 183 & $45.98 \%$ \\
& Bachelor not yet & 215 & $54.02 \%$ \\
\hline Typology of Student Genetic Personality & Sensing & 107 & $26.13 \%$ \\
& Thinking & 99 & $24.87 \%$ \\
& Intuiting & 79 & $19.85 \%$ \\
& Feeling & 78 & $19.60 \%$ \\
& Instinct & 38 & $9.55 \%$ \\
\hline
\end{tabular}

Source: Internal data processed 


\section{Outer Model Testing}

The testing phase of the measurement model includes testing for Convergent Validity, Discriminant Validity, and Composite Reliability. The results of the PLS analysis can be used to test the research hypothesis if all indicators in the PLS model have met requirements of those three testing phases.

\section{Convergent Validity Testing}

Convergent validity test was done by looking at the loading factor value of each indicator to the construct. For confirmatory research, the loading factor limit used is 0.7 , while 0.6 is for exploratory research, and 0.5 is for development research (Ghozali, 2014). Because this research is a confirmatory stud$y$, the loading factor limit used is 0.7. The estimated PLS model are shown in Figure 2.

Several indicators have a loading factor below 0.7 so it is declared invalid and must be dropped from the model. Estimation results of the model after an invalid indicator is dropped are shown in Figure 3.



Figure 2. PLS Model Estimation Measurement Model

Source: Internal data processed by SmartPLS 3.0

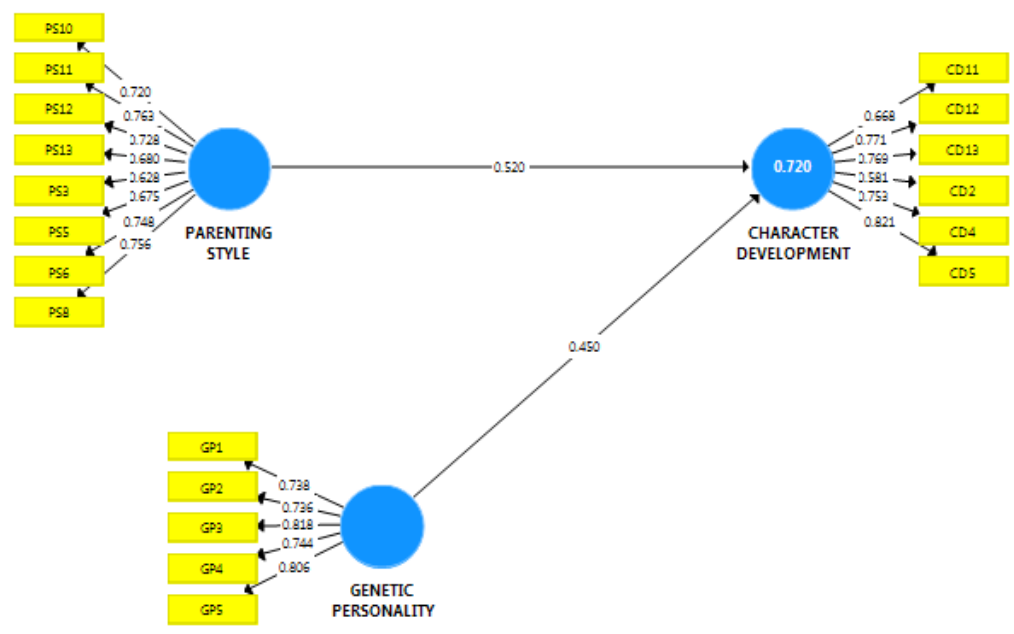

Figure 3. PLS Model Estimation Valid Model Source: Internal data processed by SmartPLS 3.0 
Based on the estimation results of the PLS model presented in Figure 3, all indicators already have a loading factor value above 0.7 so that the model meets convergent validity requirements. Besides looking at the loading factor value of each indicator, convergent validity is also assessed from the AVE value of each construct. The PLS model is declared to have met convergent validity if the AVE value of each construct is $>0.5$ (Ghozali, 2014). The AVE value for each construct can be seen in Table 3 .

Table 3. Average Variance Extracted Value (AVE)

\begin{tabular}{lr}
\hline & Average Variance Extracted (AVE) \\
\hline CD & 0.535 \\
GP & 0.592 \\
PS & 0.509 \\
\hline
\end{tabular}

Source: Internal data processed by SmartPLS 3.0

Based on the results of PLS analysis in Table 3, the value of AVE for all constructs both in the form of dimensions and variables has exceeded 0.5. It indicates that all indicators in each construct have met the required convergent validity criteria.

\section{Descriminant Validity Testing}

Discriminant validity was carried out to ensure that each concept of each latent variable is different from the other variables. The model has good discriminant validity if the AVE squared value of each exogenous construct (the value on the diagonal) exceeds the correlation between construct and other constructs (values below the diagonal) or the values are above of $0.7(>0.7)$ (Ghozali, 2014). The discriminant validity test results are obtained, as presented in Table 4.

Table 4. Discriminant Validity Value

\begin{tabular}{lrrr}
\hline & CD & GP & PS \\
\hline CD & 0.732 & & \\
GP & 0.725 & 0.769 & \\
PS & 0.757 & 0.528 & 0.714 \\
\hline
\end{tabular}

Source: Internal data processed by SmartPLS 3.0

The results of the discriminant validity test in Table 4 show that all constructs have the AVE square root value above the cor- relation value with other latent constructs. Thus, it can be concluded that the model meets discriminant validity.

\section{Composit Reliabitily Testing}

Construct reliability can be assessed from the Alpha Cronbach value and the Composite Reliability value of each construct. The recommended composite reliability and Cronbach's alpha values are more than 0.7. However, in development research, because the loading factor limit is low (0.5), low composite reliability and Cronbach's Alpha values can still be accepted as long as convergent and discriminant validity requirements have been met (Ghozali, 2014).

Table 5. Composite Reliability Value

\begin{tabular}{lrr}
\hline & Cronbach's Alpha & Composite Reliability \\
\hline CD & 0.822 & 0.872 \\
GP & 0.827 & 0.878 \\
PS & 0.862 & 0.892 \\
\hline
\end{tabular}

Source: Internal data processed by SmartPLS 3.0

Table 5 show that all constructs have composite reliability and Cronbach's Alpha values $>0.7$. In conclusion, all constructs have met the required reliability.

\section{Inner Model Testing}

Testing the inner model includes testing the significance of direct effects and measuring the magnitude of the influence exogenous on endogenous variables. With the bootstrapping technique, $\mathrm{R}$ Square values and significance test values are obtained, presented in Table 6.

Table 6. R Square Value

\begin{tabular}{rrr}
\hline & R Square & R Square Adjusted \\
\hline CD & 0.720 & 0.718 \\
\hline
\end{tabular}

Source: Internal data processed by SmartPLS 3.0

Based on Table 6, the R Square value of 0.720 means that the child character development variable can be explained by parenting style and genetic personality variables of $72.0 \%$. Meanwhile, the remaining $28 \%$ is explained by other variables not discussed in this study. 
Table 7. Value of Significance Test Results

\begin{tabular}{lrrr}
\hline & Original Sample (O) & T Statistics $(\mid \mathbf{O} /$ STDEV $\mid)$ & P Values \\
\hline GP -> CD & 0.450 & 9.298 & 0.000 \\
PS -> CD & 0.520 & 13.585 & 0.000 \\
\hline
\end{tabular}

Source: Internal data processed by SmartPLS 3.0

Table 7 illustrates the findings of the study. Each point is elaborated as follows.

The Influence of Parenting Style on the Development of Children's Character

The research findings show that parenting style has a positive and significant influence on the character development of children in Aya Sophia Foundation Islamic School. It is evidenced by the p-value of 0.000 which is smaller than 0.05 and the statistic $T$ value of 13.585 which is greater than 1.96. The original sample value is 0.520 which is positive, so, it is an indication that the $\mathrm{H} 1$ hypothesis is accepted.

The findings of this study are in line with the Bronfenbrenner Ecological Theory which states that child development is influenced by five environmental systems that range from interpersonal interactions to broader cultural influences. Bronfenbrenner refers to these systems as microsystems, mesosystems, ecosystems, macrosystems, and chronosystems. In early childhood, the most dominant influence is the microsystem in which children spend a lot of time. Some contexts in this system include family, peers, school, and neighbors (Santrock, 2008). However, it does not mean that other environmental systems do not contribute to children's development. Mesosystems are inter-microsystem links such as experiences in families and schools, ecosystems are stakeholder policies related to child development, and macrosystems such as community culture also influence children's development. The condition of sociohistoric (chronosystem) is undeniably influential, where the 21 st-century children are the generation of $Z$ which is inseparable from the influence of media and technology development. Aziz (2012) states that the family plays a vital role in the formation and development of character for each member, especially children.
The findings in this study are also in line with the results of Huver et al. which show that parenting style influences the personality development of children (Huver et al., 2010). In addition, it is also in line with the research results of Talib et al. which state that parenting style influences children's attitudes (Talib et al., 2011) and Efobi and Nwokolo's research results which show that parenting style has an impact on children's development (Efobi \& Nwokolo, 2014).

Based on the results of this study, character development in schools, especially in Early Childhood Education institutions, involves the role of parents. Parenting education programs in the form of training and workshops in an effort to align parenting in family and the process of character building in schools need to be a major concern.

The Influence of Genetic Personality on Children's Character Development

Research findings indicate that genetic personality has a positive and significant influence on the development of children's character at Aya Sophia Foundation Islamic School. It is evidenced by the p-value of 0.000 which is smaller than 0.05 and the statistic $\mathrm{T}$ value of 9.298 which is greater than 1.96. The original sample value is 0.450 which is positive, so the $\mathrm{H} 2$ hypothesis is accepted.

The findings of this study corroborate the Dryden and Vos research in Musrofi (2011) which states that each child has potentially a unique character. It is in accordance with the opinion of Murakami (2013) which states that each person is unique. No two sets of genes are exactly the same, no two people are exactly the same. The difference in each person is not only manifested in the face or appearance, but also in nature and abilities. Misbach (2010) reinforces opinion above that in the context 
of nature, a person's character is influenced by a genetic structure which is a blueprint of a person's strengths and weaknesses and becomes a "code" for each individual that is permanent. Poniman and Mangussara (2012) state that phenotype is influenced by genotype and environmental factors. One of the determining genotypes is genetic personality, which is an innate character associated with the dominance of the work system of the brain. The results of data analysis show that the genetic personality of children in Aya Sophia Foundation Islamic School is dominated by $27 \%$ sensing, then $25 \%$ feeling, $20 \%$ thinking and intuition respectively, and $8 \%$ instinct. Based on the results of this study, it should be the development of children's character in schools, especially in institutions of Early Childhood Education also pay attention to the genetic personality factors of children. Genetic personality identification can be done at the beginning of the school year and schools can collaborate with psychological institutions or human resource development institutions that are affordable.

The findings in this study are also in line with the results of neuroscience research which states that there is a very close relationship between a person's psychological condition and the work system of his brain structure. Meanwhile, the development of dermatoglyphics and dactyloscopy-research related to the structure of fingerprints illustrates a relationship between biological structures, in this case, fingerprinting with the brain's work system so it can be revealed the relationship between fingerprint patterns with interdisciplinary various fields of science including psychology and education. Dr. Mary Lai, Ph.D., MME from Taiwan is one of the educators who use the benefits of fingerprinting and dermatoglyphics research in parental counseling (Misbach, 2010).

The results of this study support the opinion of Poniman and Mangussara (2012) that phenotype is influenced by genotype and environmental factors. In this case, the character is a phenotype, parenting style is part of environmental factors, whereas ge- netic personality is part of genotype factors. Murakami (2012) states that each gene contains a lot of information. Genetics greatly influences the behavior of a species, though on the other hand, the environment is also believed to play an important role. Research on genetic links to character is still being conducted until now.

The results of this study corroborate several previous studies, one of which is by Ferguson (2010) that genetics influence antisocial character and behavior by $56 \%$. Miles and Carey (1997) stated that genetic and environmental factors influence children's aggressive behavior by $50 \%$ each. Environmental factors that have a strong influence are a family environment. Meanwhile, Carey and DiLalla (1994) stated that genetic factors influence character with a percentage between $30 \%$ to $60 \%$.

Based on the results of this study, it should develop the character of children in schools, especially in Early Childhood Education institutions to pay attention together between the factors of parenting style of children's genetic personality. Educational programs about developing children's character based on parenting and genetic personality should continue to be done both to teachers as educators in the school environment and parents as educators in the family environment.

The characters developed at the Aya Sophia Foundation Islamic School refer to the institution's vision, focusing on sholeh, intelligent, and independent characters. The three characters are also in accordance with character education guidelines set by the Ministry of Education and Culture about the 18 character values that need to be developed. Religious, honest, tolerance, care for the environment, and peace-loving are included in the character of sholeh. Meanwhile, curiosity, interest in reading, and appreciating achievements are included in intelligent characters. Independence also includes discipline, hard work, care for the environment, and responsibility. Equalization of perception between school and parents (family) related to the character developed was car- 
ried out intensively since the beginning of the new school year in the hope that there is harmony between the school and family environment.

\section{Conclusion}

This research is a survey conducted at Aya Sophia Foundation Islamic School in Tangerang Regency to get a picture of the influence of parenting style and genetic personality on the development of children's character. Based on the results of the study, the following conclusions can be drawn. (1) Parenting style provides a positive and significant influence on the development of children's character at Aya Sophia Foundation Islamic School. It means that the more positive the parenting pattern gets, the better the character development process of the child. (2) Genetic personality has a positive and significant influence on the development of children's character at Aya Sophia Foundation Islamic School. It means that the better the identification of genetic personality gets, the better the character development process of children. The results of data analysis show that the genetic personality of children in Aya Sophia Foundation Islamic School is dominated by sensing by $26.13 \%$, then thinking $24.87 \%$, intuiting $19.85 \%$, feeling 19.60, and instincts $9.55 \%$.

\section{References}

Abidin, A. R. (2011). Analisis gender pada gaya pengasuhan, proses pembelajaran di kelas, perilaku sosial dan prestasi belajar siswa SMA di Kota Bogor. Master Thesis, Institut Pertanian Bogor, Bogor.

Afifah, A. (2019). KPAI terima pengaduan 4.885 kasus anak. Retrieved October 15, 2019, from Dakta.com: Bijak dan cerdas website: http://www.dakta. com/news/17920/selama-2018-kpaiterima-pengaduan-4885-kasus-anak

Aziz, H. A. (2012). Pendidikan karakter berpusat pada hati. Jakarta: $\mathrm{Al}$ Mawardi Prima.
Carey, G., \& DiLalla, D. L. (1994). Personality and psychopathology: Genetic perspectives. Journal of Abnormal Psychology, 103(1), 32-43. https://doi.org/10.1037/0021-843X. 103.1.32

Curriculum Center for the Research and Development Agency of the Ministry of National Education. (2011). Pedoman pelaksanaan pendidikan karakter. Jakarta: Curriculum Center for the Research and Development Agency of the Ministry of National Education.

Efobi, A., \& Nwokolo, C. (2014). Relationship between parenting styles and tendency to bullying behaviour among adolescents. Journal of Education \& Human Development, 3(1), 507-521. Retrieved from http://jehdnet.com/journals/jehd/V ol_3_No_1_March_2014/27.pdf

Ferguson, C. J. (2010). Genetic contributions to antisocial personality and behavior: A meta-analytic review from an evolutionary perspective. The Journal of Social Psychology, 150(2), 160-180. Retrieved from http://www.christo pherjferguson.com/evmeta.pdf

Ghozali, I. (2014). Structural Equation Modeling: Metode alternatif dengan Partial Least Square. Semarang: Badan Penerbit Universitas Diponegoro.

Government Regulation No. 21 of 1994 on the the Implementation of Family Welfare Development. , (1994).

Hasnain, N., Faraz, B., \& Adlakha, P. (2013). Self-esteem and happiness of children and mothers of different parental authority. The International Journal Of Humanities \& Social Studies, 1(3), 1-6. Retrieved from http://inter nationaljournalcorner.com/index.php /theijhss/article/view/128036/0

Huver, R. M. E., Otten, R., de Vries, H., \& Engels, R. C. M. E. (2010). Personality and parenting style in parents of 
adolescents. Journal of Adolescence, 33(3), 395-402. https://doi.org/ 10.1016/j.adolescence.2009.07.012

Jonynienè, J., \& Kern, R. M. (2012). Individual psychology lifestyles and parenting style in Lithuanian parents of 6- to 12-year-olds. International Journal of Psychology: A Biopsychosocial Approach / Tarptautinis Psichilogijos Žurnalas: Biopsichosocialinis Požiūris, 11(11), 89-117. https://doi.org/10.7220/ 1941-7233.11.5

Law of Republic of Indonesia No. 20 of 2003 on National Education System. , (2003).

Miles, D. R., \& Carey, G. (1997). Genetic and environmental architecture on human aggression. Journal of Personality and Social Psychology, 72(1), 207-217. https://doi.org/ 10.1037/0022-3514.72.1.207

Misbach, I. H. (2010). Dahsyatnya sidik jari: Menguak bakat dan potensi untuk merancang masa depan melalui fingerprint analysis. Jakarta: Visimedia.

Murakami, K. (2012). The miracle of DNA. Bandung: Mizan Media Utama.

Murakami, K. (2013). Misteri DNA. Jakarta: Gramedia.

Musrofi, M. (2011). Potensi preneur. Surakarta: Talents Center.

Nyarko, K. (2011). The influence of authoritative parenting style on adolescents' academic achievement. American Journal of Social and Management Sciences, 2(3), 278-282. https://doi.org/10.5251/ajsms.2011. 2.3.278.282

Oktafiany, N. D., Solihatin, E., \& Japar, M. (2013). Hubungan pola asuh orang tua dengan kecerdasan emosional siswa di SMP Diponegoro 1 Jakarta. Jurnal PPKN UNJ Online, 1(2), 1-15. Retrieved from https://dokumen. tips/documents/hubungan-pola- asuh-orangtua-dengan-kecerdasanemosional-siswa-di-smp-diponegoro. html

Othman, N., \& Khairollah, S. (2013). Exploring the relationship between Islamic personality and parenting style. International Journal of Islamic Thought (IJIT), 4, 48-57. Retrieved from http://journalarticle.ukm.my/ 6784/

Poniman, F., \& Mangussara, R. A. (2012). Konsep PALUGADA. Jakarta: STIFIn Institute.

Poniman, F., \& Mangussara, R. A. (2013). STIFIn personality. Jakarta: STIFIn Institute.

Poniman, F., Nugroho, I., \& Azzaini, J. (2014). Kubik leadership: Solusi esensial meraih sukses dan hidup mulia. Jakarta: PT Gramedia Pustaka Utama.

Pratiwi, S., \& Ekowarni, E. (2015). Kecerdasan moral anak usia prasekolah etnis Cina ditinjau dari gaya pengasuhan orangtua. Proceeding Seminar Nasional Positive Psychology 2015. Surabaya: Unika Widya Mandala.

Puspitawati, H., \& Sarma, M. (2012). Sinergisme keluarga dan sekolah. Bogor: IPB Press.

Regulation of the Minister of Education and Culture No. 11 of 2015 on the Organization and Implementation of the Ministry of Education and Culture. , (2015).

Robinson, C. C., Mandleco, B., Olsen, S. F., \& Hart, C. H. (1995). Authoritative, authoritarian, and permissive parenting practices: Development of a new measure. Psychological Reports, 77(3), 819-830. https://doi.org/ 10.2466/pr0.1995.77.3.819

Roman, N. V., Davids, E. L., Moyo, A., Schilder, L., Lacante, M., \& Lens, W. (2015). Parenting styles and 
psychological needs influences on adolescent life goals and aspirations in a South African setting. Journal of Psychology in Africa, 25(4), 305-312. https://doi.org/10.1080/14330237.2 015.1078087

Samani, M., \& Hariyanto, H. (2011). Konsep dan model pendidikan karakter. Bandung: Remaja Rosdakarya.

Santrock, J. W. (2008). Educational psychology (3rd ed.). New York, NY: McGraw-Hill.

Setiawan, D. (2018). KPAI catat anak dimanfaatkan jadi kurir narkoba. Retrieved October 15, 2019, from
Komisi Perlindungan Anak Indonesia website: https://www.kpai.go.id/ berita/kpai-catat-anak-dimanfaatkanjadi-kurir-narkoba

Talib, J., Mohamad, Z., \& Mamat, M. (2011). Effects of parenting style on children development. World Journal of Social Sciences, 1(2), 14-35.

Utomo, D. (2014). Intensi perilaku prososial anak ditinjau dari gaya pengasuhan. Cognicia, 2(1). Retrieved from http://ejournal.umm.ac.id/index.php /cognicia/article/view/1817 